\title{
HIGHER EDUCATION IN EAST AFRICA
}

$\mathrm{I}_{\mathrm{B}}^{\mathrm{N}}$ 1954, a delegation, headed by Dr. (now Sir) Eric Ashby, was appointed to assist in planning the development of Makerere College, Uganda. In addition to indicating the general scope of the development which it thought appropriate, the delegation also made reference to the broad problem of developing higher education in East Africa as a whole. As a result, a working party, under the chairmanship of Sir Alexander Carr-Saunders, visited East Africa in July 1955, to review in greater detail the requirements of higher education. Its findings were published in a White Paper ${ }^{1}$, in which the Governments of Kenya, Tanganyika, Uganda and Zanzibar fully accepted the desirability of further university college development, within the scope of a single University of East Africa.

A second working party, under the leadership of Dr. J. F. Lockwood, visited East Africa in July 1958 to examine proposals for the creation of new institutions of higher education, in particular within the framework of a University of East Africa.

Its report ${ }^{2}$, recently published, contains four main recommendations, which are being considered by the East African Governments. (1) By re-organization and extension, the Royal Technical College of East Africa, in Nairobi, should, without delay, become a university college of a new type, in which academic and professional courses of equal standing would have their place with Faculties of Science, Arts, Engineering and Special Professional Studies. (2) That plans should be formed for the establishment of an inter-territorial university college in Tanganyika at Morogoro, to be opened in 1965-66, or as soon thereafter as possible. (3) That a university of East Africa should be created by 1966 and that the university colleges then existing, and any which may be founded thereafter, should be associated as constituent colleges of the university. (4) Since the carrying out of these recommendations will guarantee adequate provision for higher technological and professional training for some years ahead, no additional institutions offering facilities for these kinds of training should at present be contemplated.
If these recommendations are accepted the new University of East Africa would have as its constituent colleges, Makerere College, the Royal College of East Africa (the reorganized Royal Technical College) and the new university college in Tanganyika. The report adds: "The inter-racial character of the colleges we take for granted as an indispensable element in their fully liberal nature and outlook". That they should also be wholly inter-territorial was likely for many years to be a vital necessity in terms both of academic need and of finance.

It is suggested that since the college in Nairobi would begin its career as a university college under the same system which now applies to Makerere College, students of the reconstructed college would work for degrees of the University of London, under a scheme of special relationship. The University of East Africa, following its foundation, would grant its own degrees, for which students of all the colleges would read. Since the university college in Tanganyika would probably not begin its teaching until after 1966, students of this college would, at the outset, read for degrees of the newly established university.

Though realizing that its proposals are modest, the working party stresses that the cost, in terms both of capital and recurrent expenditure, will be high, and points out that the several Governments will be unlikely to be able to meet capital expenditure from their own joint resources. "The compulsion of their present circumstances will thus force them to lean heavily on expectations of generous grants from Colonial Development and Welfare funds."

The report concludes with the hope that financial help will be forthcoming, for the individual colleges, from non-official sources, and pays tribute to generous gifts, which the Gandhi Memorial Academy Society has made to the Royal Technical College.

\section{Mortimer}

${ }^{1}$ Higher Education in East Africa. Pp. 123. (Entebbe, 1958.)

${ }^{2}$ Report of the Working Party on Higher Education in East Africa July-August 1958. Pp. ii +48. (Nairobi : Government Printer, 1959.) Sh. 3 .

\section{GLOEOSPORIUM IN APPLE STEM WOUNDS}

\begin{abstract}
$\mathrm{T}$ WO contributions on Gloeosporium in apple stem wounds have recently appeared $(J$. Hort. Sci., 32, No. 2, 1959). R. O. Sharples has reported on an investigation of the response of apple stems to wound infections by the fungus Gloeosporium perennans. In anatomical studies relating to the establish. ment of infections on apple branches he has shown that the defensive mechanism of the host includes the production of suberized barriers by bark phellogens and the blocking of xylem vessels by gum deposition. These responses follow wounding, whether or not the wounds are inoculated with $G$. perennans; but the presence of the fungus delays the response. Accordingly the size and form of lesion induced by inoculation are largely determined by the effect of the fungus in postponing the normal wound healing process.
\end{abstract}

This effect, and consequently penetration by the pathogen, is greatest during the period of host dormancy. Invasion occurs most rapidly through the sieve-tubes and the vessels and fibres of the outer xylem ; the longitudinal intercellular spread of hyphæ through the cortex is slower.

Intracellular infection of the pith and medullary ray cells occurs in pruning-wound infections. When the progress of the infection is arrested, the phellogen and cambium lay down barriers of callus tissue consisting of parenchymatous outer cells surrounding a core of wound wood. After the lesion has been thus isolated, the fungus persists as a saprophyte and eventually forms acervuli on the exposed dead host tissue. A limited spread of infection past the suberized barriers occasionally appears to take 
place by way of the fibre bundles of the inner cortex.

On the same topic, A. T. K. Cooke has observed that Gloeosporium inoculations of pruning wounds on apple shoots are unlike branch wounds in that the cut tips of shoots are more or less susceptible to infection throughout the year, and that, although the extent of the infection is subject to the same host reactions as in lateral branch cankers, the normal healing process may be affected by seasonal conditions. This emerged in a comparison of the behaviour of infected pruning cuts made on shoots at comparable times in successive years. Sporulation on infected shoots was found to be greater in Novernber than in March infections, beginning in both instances after one month. Infections initiated during July first spored in December and produced very few conidia. Like the branch infections studied during 1953-54, the shoot cankers yielded considerable numbers of conidia in the warm, wet months of December 1956February 1957. The peak spore collection from the shoot cankers was in the June and July following inoculation, this being also a peak period for sporulation on the branch cankers.

\section{AIR SURVEYS AND THE SOCIAL SCIENTIST \\ BY LEO SILBERMAN \\ University of Chicago}

$\mathrm{C}$ O-OPERATION between the air survey team $A$ on one hand, and economists and social surveyors on the other, is likely to be greatly extended in the near future. During the War photo-interpreters had to get along without systematic ground checks, and the relative rarity of combined studies of area sample surveys using questionnaires and air photographic coverage must be ascribed to a legacy from war-time.

The advantages of combined operations are distributed equally between photogrammetrist and social student. To the uses already made of air photography, the insights of the social scientists capable of interpolating more social and economic information from the records add further facts to those already known. To the questionnaire survey the air photograph gives a much greater generality. The samples can be extrapolated by multiplying the data for each typical unit by the total of this stratum found on the photographs. This will provide an up-to-date sampling frame which in under-developed countries (though not only there) is usually lacking ${ }^{1}$. By defining unambiguously the strata of which a regional population is composed, facilitating greater control, and allowing the ground surveyor to dispense with a large, often ill-educated and sketchily supervised staff, a better and spoedier report can be furnished; this is often of great 'political' importance to the client. The time factor is sometimes crucial.

Photogrammetrist and sociogrammetrist in such a combined survey make their decisions together on the most practical scale of photography ; the size of the ground sample that will give confidence in the statistical estimates; and the planning uses to which the results can be put. Quantitative information is only part of the expected findings: attention is often focused on the use made of space and the configuration of a neighbourhood. However, social statistics will always cover a wide field, ranging from the count of slum properties to evidence of the spread of sleeping sickness.

Air censuses taken of nomads in Palestine in the days of the British mandate and the censuses of Liberia and of Columbia both taken from the air are quantitative assessments of this kind. Land-use studies in Malaya, making good use of the expensive photographs taken during the anti-terrorist campaigns and supplemented by family budget studies in that country, can be mapped so that hypotheses can be tested with the use of overlays. A real property inventory is essential to a sociogrammetric survey but the use of such a survey in national and regional income investigations and capital growth and change studies is still to be fully appreciated.

Regional comparisons are particularly important where there are jealousies between areas, and each claims self (that is, locally based) government, as in a number of West African countries, irrespective of whether it is economically feasible. By giving the discussion some underpinning of fact the scales might conceivably be tipped towards a rational economic solution. By comparisons between cognate regions we can appraise to what extent, with like endowments, policy or location has made labour and capital more productive. Is it a nearby market, or education, or a longer period of peace that explains differential incomes of similar regions ? The analyst will not only wish to discover, as in the Gambia study of the Directorate of Oversea Geological Surveys, whether more rice is grown (a matter of political importance and controversy) but also why more rice is grown. The term 'survey' implies study before planning. A country like Ceylon taking a measure of its real resources, a project of the Colombo Plan, will also need to find out about its man-power, both quantitatively and, by the style of houses and state of agriculture, qualitatively ${ }^{2}$. The Sudan not only wants to know where irrigation is technically feasible but also where there are Sudanese willing to take advantage of the arable land. The country cannot absorb a limitless influx of foreigners from the west and north without creating a security problem.

Once a clear picture emerges how an area works, the siting of a technical college or a new village becomes clear. In built-up areas of rapid expansion public utility companies will want to know where and how the towns are spreading, so that offices can be strategically located, space reserved, and telephone lines not be intersected by other services above and below ground ${ }^{3}$. The ground survey establishes to what extent houses are being subdivided and branch or independent line subscribers being added. The state of the yards and many other things will tell us whether the area is improving or deteriorating. In each area contrary influences are at work, each seeking dominance, as they spread from the various centres, and the racial strife of so many citios shows what bad neighbours peoples of different antecedents and standards of living make4.

'Ecological statistics' can give in figures the area 'profiles's, for air photographs do not speak to everyone equally eloquently, just as maps and tables are 